\title{
Keanekaragaman Jenis Tumbuhan Obat yang Dimanfaatkan oleh Pengobat Tradisional (Battra) Suku Dayak Mahap dan Suku Melayu di Desa Tembesuk Kabupaten Sekadau
}

\author{
Sofia Aliza Maharani ${ }^{*}$, Gusti Eva Tavita $^{2}$, Yeni Mariani ${ }^{3}$, Fathul Yusro ${ }^{4}$ \\ ${ }^{1,2,3,4}$ Prodi Kehutanan, Fakultas Kehutanan Universitas Tanjungpura Pontianak, Kalimantan Barat \\ *Koresponden email: yeni.mariani81@gmail.com
}

Diterima: 2 September 2021

Disetujui: 4 Oktober 2021

\begin{abstract}
The Malays and the Dayak are the dominant tribes in West Kalimantan. Different tribes have different species of plants or the way they use medicinal plants. This study aims to analyze the type, processing method, and the use method of medicinal plants by traditional healers (Battra) from the Malay and Dayak Mahap tribes in Tembesuk village, Sekadau Regency. This study used a survey method, and the selection of respondents (Batrra) was carried out by purposive sampling technique. In Tembesuk Village, 8 Battra consist of 5 Malays and 3 Dayak Mahap people. The results showed that 80 species of plants were used by Batrra in Tembesuk village. Sixty species are distributed in the Malay tribe traditional healers, while the Dayak Mahap tribe traditional healers use 35 species. The plant part with the highest uses are leaves $(60 \%$ of the Malays and $64.44 \%$ of the Dayak Mahap). The most common processing method is boiled (41.54\% of the Malays and $41.18 \%$ of the Dayak Mahap), the way of use is drunk (35.82\% of the Malays, and 41.18\% Dayak Mahap). Most of the plants are wild (66.67\% Malay and 58.33\% Dayak Mahap), and the plant family with extensive use is Zingiberaceae (six plants in Malay and five in Dayak Mahap).
\end{abstract}

Keywords: Tembesuk village, traditional healers, Dayak Mahap tribe, Melayu tribe, medicinal plants

\section{Abstrak}

Suku Melayu dan Suku Dayak merupakan suku dominan yang terdapat di Kalimantan Barat. Berbeda suku maka berbeda pula jenis tumbuhan ataupun cara mereka dalam memanfaatkan tumbuhan obat. Tujuan dari penelitian ini yaitu menganalisis jenis, cara pengolahan dan penggunaan tumbuhan obat oleh pengobat tradisional (Battra) dari Suku Melayu dan Suku Dayak Mahap di Desa Tembesuk Kabupaten Sekadau. Penelitian ini menggunakan metode survey dan pemilihan responden (Battra) dilakukan dengan teknik purposive sampling. Di Desa Tembesuk terdapat 8 orang Batrra yang terdiri dari 5 orang Suku Melayu dan 3 orang Suku Dayak Mahap. Hasil penelitian menunjukkan terdapat 80 jenis tumbuhan obat yang dimanfaatkan dan terdistribusi pada Battra Suku Melayu sebanyak 60 jenis dan pada Suku Dayak Mahap sebanyak 35 jenis. Penggunaan tertinggi yaitu pada bagian daun (60\% Suku Melayu dan 64,44\% Dayak Mahap), cara pengolahan direbus (41,54\% Suku Melayu dan 41,18\% Suku Dayak Mahap), cara penggunaan diminum (35,82\% Suku Melayu dan 41,18\% Suku Dayak Mahap), status tumbuhan liar (66,67\% Suku Melayu dan 58,33\% Suku Dayak Mahap) dan famili Zingiberaceae (6 tanaman pada Suku Melayu dan 5 tanaman pada Suku Dayak Mahap).

Kata Kunci: Desa Tembesuk, pengobat tradisional, suku Dayak Mahap, suku Melayu, tumbuhan obat

\section{Pendahuluan}

Tumbuhan obat merupakan bagian atau keseluruhan bagian dari tumbuhan yang didalamnya terkandung berbagai jenis komponen bioaktif dan berkhasiat dalam pengobatan [1]. Tumbuhan obat bagi masyarakat di Kalimantan Barat masih terus dimanfaatkan dan menjadi salah satu pilihan dalam proses pengobatan tradisional yang mereka lakukan.

Beberapa wilayah di Kalimantan Barat telah tercatat laporan penggunaan tumbuhan obat seperti di Desa Pengadang Kabupaten Sanggau [2], Desa Kelam Sejahtera, Merpak, dan Kebong Kabupaten Sintang [3][4], Desa Sungai Baru, Sungai Serabek, dan Tekarang Kabupaten Sambas [5], Desa Tonang Kabupaten Landak [6], Desa Sepandan dan Lanjak Besar Kabupaten Kapuas Hulu [7], Desa Masbangun Kabupaten Kayong Utara [8] dan Desa Tapang Semadak Kabupaten Sekadau [9]. Pemanfaatan tumbuhan obat tersebut oleh beragam suku seperti suku Melayu [2][5], Dayak Iban [7], Dayak Kanayant [6], Dayak Paus [2], Dayak Daro' dan Bukat [10], Dayak Desa [4], dan Dayak Muara [11].

Suku Melayu dan Dayak merupakan suku dominan yang terdapat di Kalimantan Barat. Perbedaan suku menyebabkan perbedaan dalam pemanfaatan tumbuhan sebagai tumbuhan obat. Perbedaan tersebut 
seperti dilaporkan oleh ref [5], dimana Suku Melayu yang ada di tiga desa di Kabupaten Sambas telah memanfaatkan sebanyak 233 jenis tumbuhan obat. Sementara itu, menurut ref. [3] Suku Dayak yang ada di tiga desa di Kabupaten Sintang memanfaatkan 198 jenis tumbuhan obat. Ref. [2] juga melaporkan bahwa terdapat perbedaan jenis tumbuhan yang dimanfaatkan oleh Suku Dayak Paus dan Suku Melayu di Desa Pengadang Kabupaten Sanggau. Adanya perbedaan-perbedaan jenis tumbuhan obat yang digunakan oleh masyarakat ataupun oleh pengobat tradisional (Battra) dari Suku Melayu dan Suku Dayak tersebut menarik untuk terus dilakukan kajian terutama pada desa-desa ataupun wilayah lain yang ada di Kalimantan Barat.

Salah satu wilayah di Kalimantan Barat yang penduduknya berasal dari Suku Melayu dan Suku Dayak adalah Kabupaten Sekadau. Di Kabupaten Sekadau, laporan mengenai pemanfaatan tumbuhan obat oleh masyarakat atau Batrra relatif sangat sedikit, dan hingga kini baru dilaporkan oleh ref. [9] bahwa di Desa Tapang Semadak masyarakatnya telah memanfaatkan 52 jenis tumbuhan obat. Pemanfaatan tumbuhan obat di desa lain di Kabupaten Sekadau dan terhadap Suku Melayu dan Suku Dayak belum dilakukan sehingga perlu untuk dilakukan kajian pemanfaatan tumbuhan obat tersebut.

Desa Tembesuk merupakan salah satu desa yang ada di Kecamatan Nanga Mahap, dimana penduduknya mayoritas berasal dari Suku Melayu dan Suku Dayak Mahap. Di desa ini, Battra masih dipercaya untuk membantu dalam pengobatan tradisonal masyarakat setempat. Namun, hingga saat ini, belum ada dokumentasi pengetahuan tumbuhan obat yang dimiliki oleh Battra dari Suku Melayu dan Suku Dayak Mahap, sehingga perlu dilakukan kajian untuk mengetahui jenis-jenis tumbuhan obat apa saja yang dimanfaatkan oleh Batrra dari Suku Melayu dan Suku Dayak Mahap di Desa Tembesuk, serta bagaimana cara pengolahan dan pemanfaatan tumbuhan obat tersebut. Tujuan dari penelitian ini yaitu menganalisis jenis dan cara pengolahan dan penggunaan tumbuhan obat oleh Battra dari Suku Melayu dan Suku Dayak Mahap di Desa Tembesuk Kabupaten Sekadau.

\section{Metode Penelitian}

\section{Waktu dan Tempat Penelitian}

Penelitian ini dilakukan pada bulan November 2020 di Desa Tembesuk Kecamatan Nanga Mahap Kabupaten Sekadau (Gambar 1).

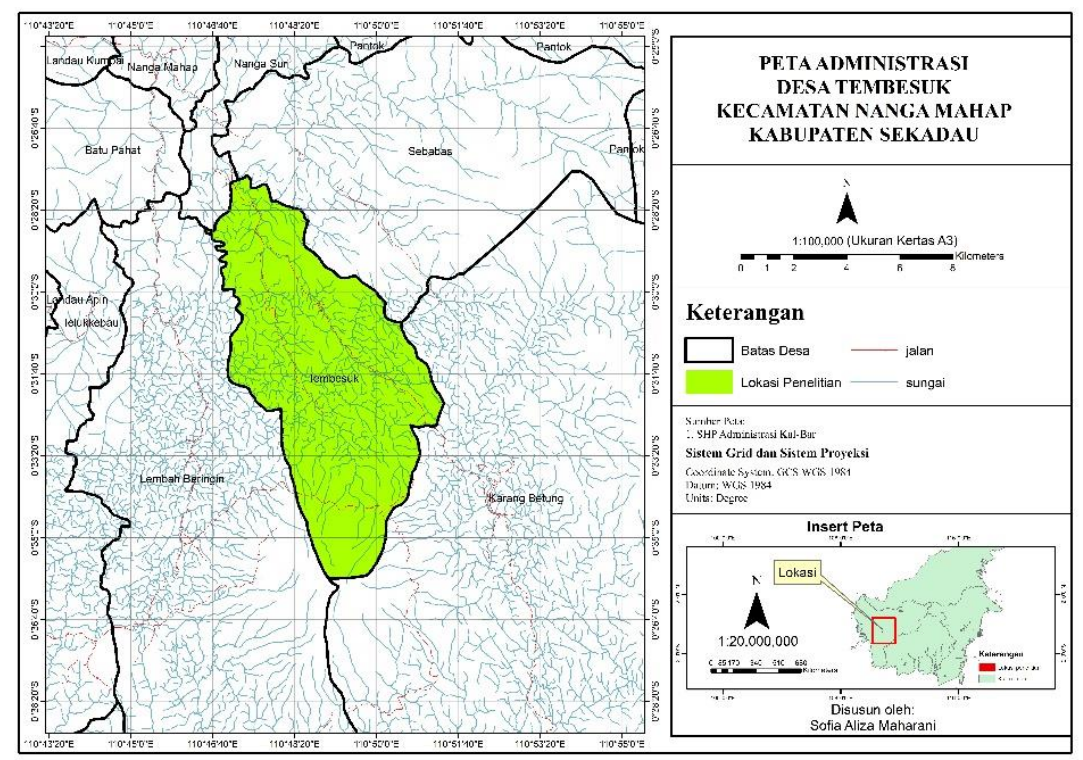

Gambar 1. Desa Tembesuk Kabupaten Sekadau (lokasi penelitian) Sumber: SHP Administrasi Kalimantan Barat 2019

\section{Alat dan Bahan}

Alat yang digunakan dalam penelitian ini adalah kamera, tally sheet, perekam suara, kuesioner, dan buku identifikasi tumbuhan obat [12]. Objek penelitian yaitu tumbuhan obat yang dimanfaatkan oleh pengobat tradisional Suku Melayu dan Suku Dayak Mahap di Desa Tembesuk.

\section{Metodologi Penelitian}

Metode survei merupakan metode yang dipakai dalam penelitian ini dan pemilihan responden dilakukan dengan teknik purposive sampling. Adapun kriteria responden adalah masyarakat setempat yang berprofesi sebagai pengobat tradisional (Battra) dari Suku Melayu dan Suku Dayak Mahap. Di Desa Tembesuk diketahui terdapat 8 orang Battra yang terdiri dari 5 orang Suku Melayu dan 3 orang Suku Dayak 
Mahap. Wawancara dilakukan terhadap Batrra dengan mengajukan beberapa pertanyaan seperti jenis tumbuhan obat apa yang digunakan dan apa khasiat tumbuhan tersebut dalam pengobatan, bagian tumbuhan apa yang dipakai, bagaimana cara pengolahan dan penggunaannya serta dimana tumbuhan tersebut diperoleh [13]. Setelah kegiatan wawancara terhadap Battra, selanjutnya dilakukan survey terhadap jenisjenis tumbuhan yang digunakan sebagai bahan pengobatan dan diidentifikasi nama ilmiahnya. Data hasil wawancara dan survey lapangan selanjutnya dilakukan analisis untuk mengetahui berapa banyak jenis tumbuhan obat yang dipakai oleh Battra, dan persentase tingkat pemanfaatan bagian tumbuhan, cara pengolahan dan penggunan serta status tanaman yang diperoleh.

\section{Hasil dan Pembahasan}

\section{Karakteristik Pengobat Tradisional (Battra) di Desa Tembesuk}

Berdasarkan hasil penelitian terdapat 8 orang Battra di Desa Tembesuk yang memanfaatkan tumbuhan obat. Sebanyak 5 orang Battra berasal dari Suku Melayu dan 3 orang Battra berasal dari Suku Dayak Mahap. Karakteristik Battra di Desa Tembesuk secara lengkap tertera pada Tabel 1.

Tabel 1. Karakteristik pengobat tradisional di Desa Tembesuk

\begin{tabular}{|c|c|c|c|c|c|}
\hline \multirow[b]{2}{*}{ No. } & \multirow[b]{2}{*}{ Karakteristik Responden } & \multicolumn{2}{|c|}{ Suku Melayu } & \multicolumn{2}{|c|}{ Suku Dayak Mahap } \\
\hline & & Jumlah & $\begin{array}{c}\text { Persentase } \\
(\%)\end{array}$ & Jumlah & Persentase $(\%)$ \\
\hline \multirow[t]{3}{*}{1.} & Gender & & & & \\
\hline & Perempuan & 3 & 60 & 0 & 0 \\
\hline & Laki-Laki & 2 & 40 & 3 & 100 \\
\hline \multirow[t]{4}{*}{2.} & Sumber Pengetahuan & & & & \\
\hline & Pengalaman Pribadi & 2 & 40 & 0 & 0 \\
\hline & Orangtua & 3 & 60 & 1 & 33,33 \\
\hline & Lainnya (Mimpi, teman, dll) & 0 & 0 & 2 & 66,67 \\
\hline \multirow[t]{4}{*}{4.} & Umur & & & & \\
\hline & $<30$ Tahun & 0 & 0 & 0 & 0 \\
\hline & 30-50 Tahun & 0 & 0 & 0 & 0 \\
\hline & $>50$ Tahun & 5 & 100 & 3 & 100 \\
\hline \multirow[t]{6}{*}{5.} & Tingkat Pendidikan & & & & \\
\hline & Tidak Sekolah & 2 & 40 & 1 & 33,33 \\
\hline & SD & 2 & 40 & 2 & 66,67 \\
\hline & SMP & 1 & 20 & 0 & 0 \\
\hline & SMA & 0 & 0 & 0 & 0 \\
\hline & Pendidikan Tinggi & 0 & 0 & 0 & 0 \\
\hline \multirow[t]{4}{*}{6.} & Agama & & & & \\
\hline & Islam & 5 & 100 & 0 & 0 \\
\hline & Katholik & 0 & 0 & 3 & 100 \\
\hline & Kristen & 0 & 0 & 0 & 0 \\
\hline \multirow[t]{4}{*}{7.} & Pendapatan Perbulan & & & & \\
\hline & $<500$ & 0 & 0 & 0 & 0 \\
\hline & $500-1 \mathrm{Jt}$ & 3 & 60 & 1 & 33,33 \\
\hline & $>1 \mathrm{Jt}$ & 2 & 40 & 2 & 66,67 \\
\hline \multirow[t]{4}{*}{8.} & Jumlah Anggota Keluarga & & & & \\
\hline & $<3$ Orang & 3 & 60 & 2 & 66,67 \\
\hline & $3 \mathrm{sd} 4$ Orang & 1 & 20 & 1 & 33,33 \\
\hline & $>4$ Orang & 1 & 20 & 0 & 0 \\
\hline \multirow[t]{3}{*}{9.} & Pekerjaan & & & & \\
\hline & Petani & 4 & 80 & 2 & 66,67 \\
\hline & $\begin{array}{l}\text { Non petani (pelajar, } \\
\text { pedagang, IRT, PNS) }\end{array}$ & 1 & 20 & 1 & 33,33 \\
\hline \multirow[t]{3}{*}{10.} & Status pernikahan & & & & \\
\hline & Belum menikah & 0 & 0 & 0 & 0 \\
\hline & Sudah menikah & 5 & 100 & 3 & 100 \\
\hline
\end{tabular}

Sumber: Hasil analisis data, 2021 
Tabel 2. Ragam jenis tumbuhan obat yang digunakan oleh Battra suku Melayu dan suku Dayak Mahap

\begin{tabular}{|c|c|c|c|c|c|c|c|c|c|c|}
\hline \multirow[b]{2}{*}{ No. } & \multirow[b]{2}{*}{ Nama Lokal } & \multirow[b]{2}{*}{ Nama Ilmiah } & \multirow[b]{2}{*}{ Famili } & \multirow{2}{*}{$\begin{array}{c}\text { Bagian } \\
\text { Tumbuhan }\end{array}$} & \multirow{2}{*}{$\begin{array}{c}\text { Cara } \\
\text { Pengelolahan }\end{array}$} & \multirow{2}{*}{$\begin{array}{c}\text { Cara } \\
\text { Penggunaan }\end{array}$} & \multirow[b]{2}{*}{ Jenis Penyakit } & \multirow{2}{*}{$\begin{array}{c}\text { Status } \\
\text { Tumbuhan }\end{array}$} & \multicolumn{2}{|c|}{ Suku Pengguna } \\
\hline & & & & & & & & & Melayu & $\begin{array}{l}\text { Dayak } \\
\text { Mahap }\end{array}$ \\
\hline 1. & $\begin{array}{l}\text { Akar } \\
\text { Gamat }\end{array}$ & Mисипа sp. & Fabaceae & Akar & Rebus & Minum & Diare & Liar & $\checkmark$ & \\
\hline 2. & $\begin{array}{l}\text { Akar } \\
\text { Rajawali }\end{array}$ & $\begin{array}{l}\text { Tinospora cordifolia } \\
\text { (Willd.) }\end{array}$ & Menispermaceae & Akar & Rebus & Minum & $\begin{array}{l}\text { Rematik, } \\
\text { demam }\end{array}$ & Liar & $\checkmark$ & \\
\hline 3. & $\begin{array}{l}\text { Akar } \\
\text { Tulang }\end{array}$ & $\begin{array}{l}\text { Aporosa frutescens } \\
\text { Blume. }\end{array}$ & Phyllanthaceae & Daun & Tumbuk & Tempel & Patah tulang & Liar & & $\checkmark$ \\
\hline 4. & Bajong & $\begin{array}{l}\text { Excoecaria } \\
\text { cochinchinensis Lour. }\end{array}$ & Euphorbiaceae & Daun & Tumbuk & Oles & $\begin{array}{l}\text { Kanker } \\
\text { tenggorokan, } \\
\text { bisul }\end{array}$ & Budidaya & $\checkmark$ & \\
\hline 5. & $\begin{array}{l}\text { Bambu } \\
\text { Kuning }\end{array}$ & Bambusa vulgaris Schrad. & Poaceae & Akar, batang & Rebus & $\begin{array}{l}\text { Minum, } \\
\text { makan }\end{array}$ & $\begin{array}{l}\text { Sakit kuning, } \\
\text { kolesterol }\end{array}$ & Budidaya & & $\checkmark$ \\
\hline 6. & $\begin{array}{l}\text { Banglai/ } \\
\text { Mangelai }\end{array}$ & $\begin{array}{l}\text { Zingiber cassumunar } \\
\text { Roxb. }\end{array}$ & Zingiberaceae & $\begin{array}{l}\text { Rimpang / } \\
\text { Rimpang }\end{array}$ & Parut / Rebus & $\begin{array}{l}\text { Kompres / } \\
\text { Minum }\end{array}$ & $\begin{array}{l}\text { Demam, pasca } \\
\text { melahirkan / } \\
\text { Sakit kuning }\end{array}$ & $\begin{array}{l}\text { Budidaya / } \\
\text { Budidaya }\end{array}$ & $\checkmark$ & $\checkmark$ \\
\hline 7. & Beroban & $\begin{array}{l}\text { Donax canniformis (G. } \\
\text { Forst.) }\end{array}$ & Marantaceae & Daun & Tumbuk & Oles & Sakit mata & Liar & $\checkmark$ & \\
\hline 8 & Bodang & Litsea elliptica Blume. & Lauraceae & Daun & Tumbuk & Gosok & Kembung & Liar & $\checkmark$ & \\
\hline 9. & $\begin{array}{l}\text { Bujang } \\
\text { Gila }\end{array}$ & $\begin{array}{l}\text { Alocasia sanderiana } \\
\text { (Bull.) }\end{array}$ & Araceae & Daun & Tumbuk & Tempel & Sakit kepala & Budidaya & & $\checkmark$ \\
\hline 10. & $\begin{array}{l}\text { Bunga } \\
\text { Pulaik }\end{array}$ & Alstonia angustiloba Miq. & Apocynaceae & $\begin{array}{l}\text { Daun, kulit } \\
\text { batang }\end{array}$ & $\begin{array}{l}\text { Rebus, seduh } \\
\text { air panas }\end{array}$ & $\begin{array}{l}\text { Minum, } \\
\text { kompres }\end{array}$ & $\begin{array}{l}\text { Demam, } \\
\text { cacingan, diare }\end{array}$ & Liar & & $\checkmark$ \\
\hline 11. & Bungkang & $\begin{array}{l}\text { Syzigium polyanthum } \\
\text { (Wight.) }\end{array}$ & Myrtaceae & $\begin{array}{l}\text { Daun, akar / } \\
\text { Daun }\end{array}$ & $\begin{array}{l}\text { Rebus / } \\
\text { Tumbuk, } \\
\text { rebus }\end{array}$ & $\begin{array}{l}\text { Makan, } \\
\text { minum / } \\
\text { Tempel, } \\
\text { minum }\end{array}$ & $\begin{array}{l}\text { Sakit perut, } \\
\text { batuk / Luka, } \\
\text { diabetes, } \\
\text { kolesterol, } \\
\text { diare, sakit gigi }\end{array}$ & $\begin{array}{l}\text { Liar / } \\
\text { Budidaya }\end{array}$ & $\checkmark$ & $\checkmark$ \\
\hline 12. & Cangkok & $\begin{array}{l}\text { Sauropus androgynus } \\
\text { Merr. }\end{array}$ & Phyllanthaceae & Daun & Tumbuk & Oles & Pelancar ASI & Budidaya & $\checkmark$ & \\
\hline 13. & $\begin{array}{l}\text { Cocor } \\
\text { Bebek / } \\
\text { Dadup }\end{array}$ & Kalanchoe pinnata (Lam.) & Crassulaceae & Daun / Daun & $\begin{array}{l}\text { Remas / } \\
\text { Tumbuk, } \\
\text { rebus }\end{array}$ & $\begin{array}{l}\text { Tempel / } \\
\text { Oles, minum }\end{array}$ & $\begin{array}{l}\text { Demam / Sakit } \\
\text { kepala, bisul, } \\
\text { sakit perut, } \\
\text { batuk }\end{array}$ & $\begin{array}{l}\text { Budidaya / } \\
\text { Budidaya }\end{array}$ & $\checkmark$ & $\checkmark$ \\
\hline 14. & Cokur & Kaempferia galanga L. & Zingiberaceae & $\begin{array}{l}\text { Daun, rimpang } \\
\text { / Daun, } \\
\text { rimpang }\end{array}$ & $\begin{array}{l}\text { Tumbuk / } \\
\text { Tumbuk, } \\
\text { rebus }\end{array}$ & $\begin{array}{l}\text { Oles / Oles, } \\
\text { minum }\end{array}$ & $\begin{array}{l}\text { Sakit perut, } \\
\text { kembung / Sakit } \\
\text { perut, batuk, } \\
\text { diare, }\end{array}$ & $\begin{array}{l}\text { Budidaya / } \\
\text { Budidaya }\end{array}$ & $\checkmark$ & $\checkmark$ \\
\hline
\end{tabular}




\begin{tabular}{|c|c|c|c|c|c|c|c|c|c|c|}
\hline \multirow[b]{2}{*}{ No. } & \multirow[b]{2}{*}{ Nama Lokal } & \multirow[b]{2}{*}{ Nama Ilmiah } & \multirow[b]{2}{*}{ Famili } & \multirow[b]{2}{*}{$\begin{array}{l}\text { Bagian } \\
\text { Tumbuhan }\end{array}$} & \multirow{2}{*}{$\begin{array}{c}\text { Cara } \\
\text { Pengelolahan }\end{array}$} & \multirow{2}{*}{$\begin{array}{c}\text { Cara } \\
\text { Penggunaan }\end{array}$} & \multirow[b]{2}{*}{ Jenis Penyakit } & \multirow[b]{2}{*}{$\begin{array}{c}\text { Status } \\
\text { Tumbuhan }\end{array}$} & \multicolumn{2}{|c|}{ Suku Pengguna } \\
\hline & & & & & & & & & Melayu & $\begin{array}{l}\text { Dayak } \\
\text { Mahap }\end{array}$ \\
\hline 15. & $\begin{array}{l}\text { Cokur } \\
\text { Belangkin }\end{array}$ & Tacca palmata Blume. & Taccaceae & Daun / Daun & $\begin{array}{l}\text { Tumbuk / } \\
\text { Tumbuk, layur }\end{array}$ & $\begin{array}{l}\text { Oles / Oles, } \\
\text { tempel }\end{array}$ & $\begin{array}{l}\text { meningkatkan } \\
\text { nafsu makan } \\
\text { Batuk / Demam, } \\
\text { sakit perut }\end{array}$ & $\begin{array}{l}\text { Budidaya / } \\
\text { Budidaya }\end{array}$ & $\checkmark$ & $\checkmark$ \\
\hline 16. & $\begin{array}{l}\text { Daun } \\
\text { Kentut }\end{array}$ & Paederia foetida $\mathrm{L}$. & Rubiaceae & Daun & Tumbuk & Oles & $\begin{array}{l}\text { Melancarkan } \\
\text { BAB }\end{array}$ & Liar & $\checkmark$ & \\
\hline 17. & $\begin{array}{l}\text { Daun } \\
\text { Syaraf }\end{array}$ & $\begin{array}{l}\text { Hemigraphis alternata } \\
\text { (Burm.f.) }\end{array}$ & Acanthaceae & Daun & Rebus & Minum & $\begin{array}{l}\text { Sakit sendi, } \\
\text { diabetes }\end{array}$ & Liar & & $\checkmark$ \\
\hline 18. & Empangel & $\begin{array}{l}\text { Clerodendrum japonicum } \\
\text { (Thunb.) }\end{array}$ & Verbenaceae & Bunga & Tumbuk & Oles & $\begin{array}{l}\text { Penghilang bau } \\
\text { badan, bisul }\end{array}$ & Liar & $\checkmark$ & \\
\hline 19. & Emponan & Syzygium sp. & Myrtaceae & Daun & Tumbuk & Oles & Demam & Liar & & $\checkmark$ \\
\hline 20. & Ensanga & Digitaria bicornis (Lam.) & Poaceae & Akar & Tumbuk & Oles & Nyeri lutut & Liar & $\checkmark$ & \\
\hline 21. & Entaban & $\begin{array}{l}\text { Poikilospermum } \\
\text { suaveolens Blume. }\end{array}$ & Urticaceae & Daun & Tumbuk & Tempel & Bisul, sariawan & Liar & & $\checkmark$ \\
\hline 22. & Entomu & $\begin{array}{l}\text { Curcuma zanthorrhiza } \\
\text { Roxb. }\end{array}$ & Zingiberaceae & Rimpang & Rebus & Minum & $\begin{array}{l}\text { Maagh, } \\
\text { keputihan }\end{array}$ & Budidaya & $\checkmark$ & \\
\hline 23. & Entuyut & $\begin{array}{l}\text { Nepenthes mirabilis } \\
\text { (Lour.) }\end{array}$ & Nepenthaceae & Akar & Tumbuk & Oles & Asma & Liar & $\checkmark$ & \\
\hline 24. & Gaharu & $\begin{array}{l}\text { Aquilaria malaccensis } \\
\text { Benth. }\end{array}$ & Thymelaeaceae & Daun & $\begin{array}{l}\text { Seduh air } \\
\text { panas }\end{array}$ & Kompres & Demam anak & Budidaya & $\checkmark$ & \\
\hline 25 & Gamut & $\begin{array}{l}\text { Myrmecodia tuberosa } \\
\text { Jack. }\end{array}$ & Rubiaceae & Umbi & Rebus & Minum & Rematik, & Liar & $\checkmark$ & \\
\hline 26. & Gandarusa & $\begin{array}{l}\text { Justicia gendarussa } \\
\text { Burm.f }\end{array}$ & Acanthaceae & Daun & Tumbuk & Oles & Demam & Budidaya & $\checkmark$ & \\
\hline 27. & Gelinggam & $\begin{array}{l}\text { Stachytarpheta } \\
\text { jamaicensis (L.) }\end{array}$ & Verbenaceae & Daun & Tumbuk & Gosok & Asma, batuk & Liar & $\checkmark$ & \\
\hline 28. & Ilang Merah & $\begin{array}{l}\text { Homalomena occulta } \\
\text { Schott. }\end{array}$ & Araceae & Daun & Tumbuk & Tempel & Struk & Budidaya & & $\checkmark$ \\
\hline 29. & Jambu Biji & Psidium guajava $\mathrm{L}$. & Myrtaceae & Akar, daun & Rebus & Minum & Diare, disentri & Liar & $\checkmark$ & \\
\hline 30. & $\begin{array}{l}\text { Jelumpang } \\
\text { Bunga }\end{array}$ & Acalypha hispida Willd. & Euphorbiaceae & Bunga & Tumbuk & Oles & $\begin{array}{l}\text { Penghilang bau } \\
\text { badan, cacingan }\end{array}$ & Liar & $\checkmark$ & \\
\hline 31 & $\begin{array}{l}\text { Jerangau } \\
\text { Sabang/ } \\
\text { Jeringau }\end{array}$ & Acorus calamus $\mathrm{L}$. & Acoraceae & $\begin{array}{l}\text { Daun / Daun, } \\
\text { rimpang }\end{array}$ & Rebus / Rebus & $\begin{array}{l}\text { Minum / } \\
\text { Tempel, } \\
\text { makan, } \\
\text { minum }\end{array}$ & $\begin{array}{l}\text { Sakit perut / } \\
\text { Sakit perut, } \\
\text { bisul, luka, } \\
\text { batuk, demam }\end{array}$ & $\begin{array}{l}\text { Budidaya / } \\
\text { Budidaya }\end{array}$ & $\checkmark$ & $\checkmark$ \\
\hline 32 & Jorin & $\begin{array}{l}\text { Archidendron pauciflorum } \\
\text { (Benth.) }\end{array}$ & Mimosaceae & Daun & Rebus & Gosok & Bengkak & Liar & $\checkmark$ & \\
\hline
\end{tabular}




\begin{tabular}{|c|c|c|c|c|c|c|c|c|c|c|}
\hline \multirow[b]{2}{*}{ No. } & \multirow[b]{2}{*}{ Nama Lokal } & \multirow[b]{2}{*}{ Nama Ilmiah } & \multirow[b]{2}{*}{ Famili } & \multirow[b]{2}{*}{$\begin{array}{l}\text { Bagian } \\
\text { Tumbuhan }\end{array}$} & \multirow[b]{2}{*}{$\begin{array}{c}\text { Cara } \\
\text { Pengelolahan }\end{array}$} & \multirow[b]{2}{*}{$\begin{array}{c}\text { Cara } \\
\text { Penggunaan }\end{array}$} & \multirow[b]{2}{*}{ Jenis Penyakit } & \multirow[b]{2}{*}{$\begin{array}{c}\text { Status } \\
\text { Tumbuhan }\end{array}$} & \multicolumn{2}{|c|}{ Suku Pengguna } \\
\hline & & & & & & & & & Melayu & $\begin{array}{l}\text { Dayak } \\
\text { Mahap }\end{array}$ \\
\hline 33. & $\begin{array}{l}\text { Juaran } \\
\text { Belang }\end{array}$ & $\begin{array}{l}\text { Graptophyllum pictum } \\
\text { Griff. }\end{array}$ & Acanthaceae & Daun & Rebus & Minum & Diare & Liar & $\checkmark$ & \\
\hline 34. & $\begin{array}{l}\text { Juaran } \\
\text { Hitam }\end{array}$ & $\begin{array}{l}\text { Graptophyllum pictum } \\
\text { Bronze. }\end{array}$ & Acanthaceae & Daun & Remas & Tempel & Sakit kepala & Liar & $\checkmark$ & \\
\hline 35. & Jungkal & Crinum asiaticum $\mathrm{L}$. & Amaryllidaceae & Daun / Daun & Layur / layur & Ikat / Ikat & $\begin{array}{l}\text { Keseleo / } \\
\text { Keseleo }\end{array}$ & Liar / Liar & $\checkmark$ & $\checkmark$ \\
\hline 36. & Kakabu & Ceiba pentandra $\mathrm{L}$. & Malvaceae & Daun & Remas & Oles & Demam & Liar & $\checkmark$ & \\
\hline 37. & Kecopok & Physalis angulata $\mathrm{L}$. & Solanaceae & Akar & Rebus & Kumur & Sakit gigi & Liar & $\checkmark$ & \\
\hline 38. & $\begin{array}{l}\text { Keladi } \\
\text { Berlayar/ } \\
\text { Patah } \\
\text { Kemudi }\end{array}$ & Elephantopus scaber L. & Asteraceae & Akar / Daun & $\begin{array}{l}\text { Rebus / } \\
\text { Tumbuk, } \\
\text { rebus }\end{array}$ & $\begin{array}{l}\text { Minum / } \\
\text { Minum }\end{array}$ & $\begin{array}{l}\text { Demam / } \\
\text { Demam, sakit } \\
\text { perut }\end{array}$ & Liar / Liar & $\checkmark$ & $\checkmark$ \\
\hline 39. & $\begin{array}{l}\text { Keladi } \\
\text { Bintik }\end{array}$ & $\begin{array}{l}\text { Dieffenbachia seguine } \\
\text { (Jacq.) }\end{array}$ & Araceae & Batang & Tidak diolah & Oles & Luka bakar & Liar & $\checkmark$ & \\
\hline 40. & $\begin{array}{l}\text { Keladi } \\
\text { Birah/ } \\
\text { Keladi }\end{array}$ & Colocasia esculenta (L.) & Araceae & $\begin{array}{l}\text { Batang / } \\
\text { Batang }\end{array}$ & $\begin{array}{l}\text { Tidak diolah / } \\
\text { Tidak diolah }\end{array}$ & Oles / Oles & $\begin{array}{l}\text { Luka bakar / } \\
\text { Luka bakar }\end{array}$ & Liar / Liar & $\checkmark$ & $\checkmark$ \\
\hline 41. & Kelor & Moringa oleifera Lam. & Moringaceae & Daun / Daun & $\begin{array}{l}\text { Remas / } \\
\text { Remas }\end{array}$ & $\begin{array}{l}\text { Minum / } \\
\text { Minum }\end{array}$ & $\begin{array}{l}\text { Rematik, } \\
\text { diabetes / } \\
\text { Kolesterol, } \\
\text { rematik, } \\
\text { diabetes }\end{array}$ & Liar / Liar & $\checkmark$ & $\checkmark$ \\
\hline 42. & $\begin{array}{l}\text { Kemangi } \\
\text { Kampung }\end{array}$ & Coleus amboinicus Lour. & Lamiaceae & Daun & Tumbuk & Minum & Asma, batuk & Liar & $\checkmark$ & \\
\hline 43. & Kemunting & $\begin{array}{l}\text { Melastoma malabathricum } \\
\text { L. }\end{array}$ & Melastomaceae & Akar, daun & Rebus & Minum & $\begin{array}{l}\text { Disentri, } \\
\text { sariawan }\end{array}$ & Liar & & $\checkmark$ \\
\hline 44. & Kepayang & Jatropha curcas L. & Euphorbiaceae & Kulit batang & Rebus & Kumur & Sakit gigi & Liar & $\checkmark$ & \\
\hline 45. & $\begin{array}{l}\text { Kumis } \\
\text { Kucing }\end{array}$ & $\begin{array}{l}\text { Orthosiphon aristatus } \\
\text { (Blume.) }\end{array}$ & Lamiaceae & $\begin{array}{l}\text { Akar, daun / } \\
\text { Akar, seluruh } \\
\text { bagian, bunga }\end{array}$ & $\begin{array}{l}\text { Rebus / } \\
\text { Rebus, seduh } \\
\text { air panas }\end{array}$ & $\begin{array}{l}\text { Minum / } \\
\text { Minum }\end{array}$ & $\begin{array}{l}\text { Malaria, } \\
\text { penyakit dalam, } \\
\text { rematik / } \\
\text { Demam, } \\
\text { diabetes }\end{array}$ & $\begin{array}{l}\text { Budidaya / } \\
\text { Liar }\end{array}$ & $\checkmark$ & $\checkmark$ \\
\hline 46. & Kumpai & $\begin{array}{l}\text { Megathyrsus maximus } \\
\text { (Jacq.) }\end{array}$ & Poaceae & Daun & Rebus & Minum & Maagh & Liar & $\checkmark$ & \\
\hline 47. & Kunyit & Curcuma longa $\mathrm{L}$. & Zingiberaceae & Rimpang & Tumbuk & Oles & $\begin{array}{l}\text { Sakit perut, } \\
\text { Sakit kuning, } \\
\text { luka }\end{array}$ & Budidaya & & $\checkmark$ \\
\hline
\end{tabular}




\begin{tabular}{|c|c|c|c|c|c|c|c|c|c|c|}
\hline \multirow[b]{2}{*}{ No. } & \multirow[b]{2}{*}{ Nama Lokal } & \multirow[b]{2}{*}{ Nama Ilmiah } & \multirow[b]{2}{*}{ Famili } & \multirow[b]{2}{*}{$\begin{array}{c}\text { Bagian } \\
\text { Tumbuhan }\end{array}$} & \multirow[b]{2}{*}{$\begin{array}{c}\text { Cara } \\
\text { Pengelolahan }\end{array}$} & \multirow[b]{2}{*}{$\begin{array}{c}\text { Cara } \\
\text { Penggunaan }\end{array}$} & \multirow[b]{2}{*}{ Jenis Penyakit } & \multirow[b]{2}{*}{$\begin{array}{c}\text { Status } \\
\text { Tumbuhan }\end{array}$} & \multicolumn{2}{|c|}{ Suku Pengguna } \\
\hline & & & & & & & & & Melayu & $\begin{array}{l}\text { Dayak } \\
\text { Mahap }\end{array}$ \\
\hline 48. & $\begin{array}{l}\text { Kunyit } \\
\text { Putih }\end{array}$ & Curcuma zedoaria Roxb. & Zingiberaceae & Rimpang & Rebus & Minum & $\begin{array}{l}\text { Penyakit dalam, } \\
\text { pasca } \\
\text { melahirkan }\end{array}$ & Liar & & $\checkmark$ \\
\hline 49. & Leyak & Zingiber officinale Roscoe. & Zingiberaceae & Rimpang & Tumbuk & Minum & $\begin{array}{l}\text { Batuk, pasca } \\
\text { melahirkan, } \\
\text { pegal linu }\end{array}$ & Budidaya & $\checkmark$ & \\
\hline 50. & $\begin{array}{l}\text { Leyak } \\
\text { Merah }\end{array}$ & $\begin{array}{l}\text { Zingiber officinale Rosc. } \\
\text { var rubrum }\end{array}$ & Zingiberaceae & $\begin{array}{l}\text { Rimpang / } \\
\text { Rimpang }\end{array}$ & $\begin{array}{l}\text { Tumbuk, } \\
\text { rebus / Rebus, } \\
\text { parut }\end{array}$ & $\begin{array}{l}\text { Tempel, } \\
\text { minum / } \\
\text { Tempel, } \\
\text { oles, minum }\end{array}$ & $\begin{array}{l}\text { Luka, pegal linu } \\
\text { / Memar, } \\
\text { meningkatkan } \\
\text { nafsu makan, } \\
\text { batuk, sakit } \\
\text { perut, pegal linu }\end{array}$ & $\begin{array}{l}\text { Budidaya / } \\
\text { Budidaya }\end{array}$ & $\checkmark$ & $\checkmark$ \\
\hline 51. & $\begin{array}{l}\text { Lidah } \\
\text { Buaya }\end{array}$ & Aloe vera $\mathrm{L}$. & Asphodelaceae & Daun & Tidak diolah & Oles & Luka bakar & Budidaya & $\checkmark$ & \\
\hline 52. & Limau Nipis & $\begin{array}{l}\text { Citrus aurantifolia } \\
\text { (Christm.) }\end{array}$ & Rutaceae & Buah, Daun & $\begin{array}{l}\text { Tumbuk, } \\
\text { rebus }\end{array}$ & Oles, minum & $\begin{array}{l}\text { Pegal linu, } \\
\text { batuk, asma }\end{array}$ & Budidaya & & $\checkmark$ \\
\hline 53. & Loban & Vitex pinnata $\mathrm{L}$. & Verbenaceae & Daun / Daun & $\begin{array}{l}\text { Tumbuk / } \\
\text { Tumbuk }\end{array}$ & $\begin{array}{l}\text { Tempel } \\
\text { /Tempel }\end{array}$ & Luka / Luka & Liar / Liar & $\checkmark$ & $\checkmark$ \\
\hline 54. & Mangkok & $\begin{array}{l}\text { Nothopanax scutellarium } \\
\text { Merr. }\end{array}$ & Araliaceae & Daun / Daun & $\begin{array}{l}\text { Tumbuk / } \\
\text { Tumbuk }\end{array}$ & Oles / Oles & $\begin{array}{l}\text { Sakit kepala, } \\
\text { sariawan / Sakit } \\
\text { kepala, luka }\end{array}$ & $\begin{array}{l}\text { Budidaya / } \\
\text { Budidaya }\end{array}$ & $\checkmark$ & $\checkmark$ \\
\hline 55. & Mengulai & Pluchea indica (L.) & Asteraceae & Daun & Tumbuk & Tempel & Sakit kepala & Liar & $\checkmark$ & \\
\hline 56. & $\begin{array}{l}\text { Pakis } \\
\text { Putih }\end{array}$ & Asplenium adiantum $\mathrm{L}$. & Aspleniaceae & Daun & Tumbuk & Oles & Bekas luka & Liar & $\checkmark$ & \\
\hline 57. & $\begin{array}{l}\text { Pakis } \\
\text { Rayap }\end{array}$ & $\begin{array}{l}\text { Selaginella doederleinii } \\
\text { Hier. }\end{array}$ & Selaginellaceae & Daun & Tumbuk & Tempel & Demam & Liar & $\checkmark$ & \\
\hline 58. & $\begin{array}{l}\text { Payak } \\
\text { Babi }\end{array}$ & $\begin{array}{l}\text { Pseudelephantopus } \\
\text { spicatus Rohr. }\end{array}$ & Asteraceae & Daun & Tumbuk & Tempel & Demam & Liar & & $\checkmark$ \\
\hline 59. & Pegage & Centella Asiatica (L.) & Apiaceae & Daun & $\begin{array}{l}\text { Tumbuk, } \\
\text { rebus }\end{array}$ & $\begin{array}{l}\text { Tempel, } \\
\text { minum }\end{array}$ & Luka, batuk & Liar & $\checkmark$ & \\
\hline 60 & $\begin{array}{l}\text { Penawar } \\
\text { Todong }\end{array}$ & $\begin{array}{l}\text { Euphorbia tithymaloides } \\
\text { L. }\end{array}$ & Euphorbiaceae & Daun & Tumbuk & Oles & $\begin{array}{l}\text { Panas dalam, } \\
\text { luka }\end{array}$ & Budidaya & & $\checkmark$ \\
\hline 61. & Pinang & Areca catechu $\mathrm{L}$. & Arecaceae & Buah & $\begin{array}{l}\text { Tumbuk, } \\
\text { bakar }\end{array}$ & Oles, makan & $\begin{array}{l}\text { Bisul, luka, } \\
\text { cacingan }\end{array}$ & Budidaya & $\checkmark$ & \\
\hline 62. & Rajang & $\begin{array}{l}\text { Dendrobium crumenatum } \\
\text { Sw. }\end{array}$ & Orchidaceae & $\begin{array}{l}\text { Seluruh } \\
\text { bagian }\end{array}$ & Tumbuk & Tempel & Sakit kepala & Liar & $\checkmark$ & \\
\hline
\end{tabular}




\begin{tabular}{|c|c|c|c|c|c|c|c|c|c|c|}
\hline \multirow[b]{2}{*}{ No. } & \multirow[b]{2}{*}{ Nama Lokal } & \multirow[b]{2}{*}{ Nama Ilmiah } & \multirow[b]{2}{*}{ Famili } & \multirow[b]{2}{*}{$\begin{array}{l}\text { Bagian } \\
\text { Tumbuhan }\end{array}$} & \multirow[b]{2}{*}{$\begin{array}{c}\text { Cara } \\
\text { Pengelolahan }\end{array}$} & \multirow[b]{2}{*}{$\begin{array}{c}\text { Cara } \\
\text { Penggunaan }\end{array}$} & \multirow[b]{2}{*}{ Jenis Penyakit } & \multirow[b]{2}{*}{$\begin{array}{l}\text { Status } \\
\text { Tumbuhan }\end{array}$} & \multicolumn{2}{|c|}{ Suku Pengguna } \\
\hline & & & & & & & & & Melayu & $\begin{array}{l}\text { Dayak } \\
\text { Mahap }\end{array}$ \\
\hline 63. & $\begin{array}{l}\text { Rampang } \\
\text { Badi }\end{array}$ & $\begin{array}{l}\text { Plectranthus } \\
\text { scutellarioides Blume. }\end{array}$ & Lamiaceae & Daun & Rebus & Minum & Penyakit dalam & Liar & & $\checkmark$ \\
\hline 64. & Riang Batu & Begonia sp. & Begoniaceae & Daun & Tumbuk & Oles & Bengkak & Budidaya & $\checkmark$ & \\
\hline 65. & Sabang & Cordyline fruticosa (L.) & Agavaceae & Daun & Rebus & Minum & Maagh & Budidaya & $\checkmark$ & \\
\hline 66. & $\begin{array}{l}\text { Saga } \\
\text { Gunting }\end{array}$ & Ipomoea quamoclit $\mathrm{L}$. & Convolvulaceae & Daun & $\begin{array}{l}\text { Tumbuk, } \\
\text { rebus }\end{array}$ & Oles, minum & Bisul, batuk & Liar & $\checkmark$ & \\
\hline 67. & Sahang & Piper nigrum $\mathrm{L}$. & Piperaceae & Daun & Rebus & Minum & Panas dingin & Budidaya & $\checkmark$ & \\
\hline 68. & Selasih & Passiflora foetida $\mathrm{L}$. & Passifloraceae & Buah & Tidak diolah & Makan & Panas dalam & Liar & $\checkmark$ & \\
\hline 69. & Semilu & Leucas lavandulifolia $\mathrm{Sm}$. & Lamiaceae & Daun & $\begin{array}{l}\text { Tumbuk, } \\
\text { rebus, remas }\end{array}$ & $\begin{array}{l}\text { Tempel, } \\
\text { minum }\end{array}$ & $\begin{array}{l}\text { Pasca } \\
\text { melahirkan, } \\
\text { sakit kepala }\end{array}$ & Liar & & $\checkmark$ \\
\hline 70. & Sengkubak & $\begin{array}{l}\text { Pycnarrhena cauliflora } \\
\text { Diels. }\end{array}$ & Menispermaceae & Daun & Remas & Oles & Demam & Liar & & $\checkmark$ \\
\hline 71. & Sidaguri & Sida acuta Burm.f & Malvaceae & Daun & Rebus & Minum & Batuk & Liar & $\checkmark$ & \\
\hline 72. & Simalakama & $\begin{array}{l}\text { Bunchosia armeniaca } \\
\text { (Cav.) }\end{array}$ & Malpighiaceae & Buah & Rebus & Oles & Mata rabun & Budidaya & $\checkmark$ & \\
\hline 73. & Sirih & Piper betle L. & Piperaceae & Daun & $\begin{array}{l}\text { Tumbuk, } \\
\text { rebus, layur }\end{array}$ & $\begin{array}{l}\text { Tempel, } \\
\text { oles, kumur }\end{array}$ & $\begin{array}{l}\text { Pegal linu, } \\
\text { bengkak, batuk }\end{array}$ & Budidaya & & $\checkmark$ \\
\hline 74. & $\begin{array}{l}\text { Sirih } \\
\text { Merah }\end{array}$ & $\begin{array}{l}\text { Piper crocatum Ruiz \& } \\
\text { Pav. }\end{array}$ & Piperaceae & Daun & $\begin{array}{l}\text { Tumbuk, } \\
\text { rebus }\end{array}$ & $\begin{array}{l}\text { Minum, } \\
\text { mandi }\end{array}$ & $\begin{array}{l}\text { Diabetes, sakit } \\
\text { perut, gatal- } \\
\text { gatal }\end{array}$ & Liar & & $\checkmark$ \\
\hline 75. & Sorai & $\begin{array}{l}\text { Cymbopogon citratus } \\
\text { Stapf. }\end{array}$ & Poaceae & $\begin{array}{l}\text { Daun / Daun, } \\
\text { Batang }\end{array}$ & $\begin{array}{l}\text { Rebus / } \\
\text { Tumbuk, } \\
\text { rebus }\end{array}$ & $\begin{array}{l}\text { Minum / } \\
\text { Gosok, } \\
\text { minum }\end{array}$ & $\begin{array}{l}\text { Batuk, rematik, } \\
\text { demam / Pegal } \\
\text { linu, keputihan, } \\
\text { sakit perut }\end{array}$ & Liar / Liar & $\checkmark$ & $\checkmark$ \\
\hline 76. & Sorai Serbat & Cymbopogon nardus (L.) & Poaceae & Daun & Rebus & Mandi & $\begin{array}{l}\text { Demam, sakit } \\
\text { perut, diabetes }\end{array}$ & Liar & $\checkmark$ & \\
\hline 77. & $\begin{array}{l}\text { Sumpak } \\
\text { Merah }\end{array}$ & $\begin{array}{l}\text { Costus speciosus (J. } \\
\text { Koenig) }\end{array}$ & Zingiberaceae & Batang & Rebus & Minum & Penyakit dalam & Liar & $\checkmark$ & \\
\hline 78. & Suruhan & Peperomia pellucida (L.) & Piperaceae & Daun/Daun & Rebus / Rebus & $\begin{array}{l}\text { Minum / } \\
\text { Minum }\end{array}$ & $\begin{array}{l}\text { Demam, sakit } \\
\text { kepala / Demam }\end{array}$ & Liar / Liar & $\checkmark$ & $\checkmark$ \\
\hline 79. & $\begin{array}{l}\text { Timau Besi/ } \\
\text { Nasik Barek }\end{array}$ & Callicarpa longifolia Lam. & Lamiaceae & Daun / Daun & Rebus / Rebus & $\begin{array}{l}\text { Minum, } \\
\text { mandi / } \\
\text { Minum }\end{array}$ & $\begin{array}{l}\text { Rematik, } \\
\text { demam / Sakit } \\
\text { kuning }\end{array}$ & Liar / Liar & $\checkmark$ & $\checkmark$ \\
\hline
\end{tabular}

Ket: Tanda (*) mengartikan pembacaan isi tabel sebelum garis miring (/) adalah Suku Melayu dan sesudah garis miring (/) adalah Suku Dayak Mahap Sumber: Hasil analisis data, 2021 
Berdasarkan hasil wawancara terhadap 8 orang Battra, diketahui jenis kelamin Battra tertinggi pada kedua suku berbeda. Berdasarkan karakteristik suku, pada Suku Melayu persentase tertinggi Battra yaitu perempuan (60\%) sedangkan pada Suku Dayak Mahap persentase tertinggi adalah laki-laki (100\%). Perbedaan ini diduga karena Suku Dayak Mahap masih terikat dengan aturan adat dan istiadat mengenai pengetahuan tumbuhan obat. Sumber pengetahuan Battra Suku Melayu paling tinggi didapatkan dari orang tua (60\%), sedangkan Battra Suku Dayak Mahap mendapatkan pengetahuan paling banyak melalui mimpi $(66,67 \%)$ yang kemudian diaplikasikan pada dunia nyata. Karakteristik usia Battra tertinggi yaitu $>50$ tahun dengan persentase pada kedua suku adalah $100 \%$ dengan pengalaman menjadi Battra paling tinggi pada pengobat tradisional Suku Melayu dan Dayak Mahap yaitu >20 tahun (60\% dan 66,67\%). Ref [14] menyatakan bahwa semakin bertambah umur seseorang maka pengetahuan yang diperoleh juga semakin bertambah. Selain menjadi Battra, responden pada kedua suku juga bekerja sebagai petani serta pedagang dan memiliki penghasilan Rp.700.000 - Rp. 1.500 .000 perbulan.

\section{Jenis-jenis tumbuhan obat yang dimanfaatkan oleh Battra}

Berdasarkan hasil wawancara terhadap 8 orang Battra, teridentifikasi 80 jenis tumbuhan obat yang dimanfaatkan oleh mereka dalam proses pengobatan tradisional (Tabel 2). Hasil ini tergolong lebih tinggi jika dibandingkan dengan beberapa penelitian lain di Kalimantan Barat seperti 59 jenis tumbuhan obat yang dimanfaatkan Battra Suku Dayak Desa di Desa Kebong dan Merpak Sintang [4], 60 jenis tumbuhan obat yang dimanfaatkan Battra Suku Kanayant di Desa Tonang Landak [6], 24 jenis tumbuhan obat yang dimanfaatkan Battra di Desa Masbangun Kayong Utara [8], dan 32 jenis tumbuhan obat yang dimanfaatkan Battra di Desa Karya Bakti Bengkayang [15].

Jika dilihat dari distribusi pemanfaatan tumbuhan obatnya, Battra Suku Melayu memanfaatkan 60 jenis tumbuhan obat dan pada Suku Dayak Mahap memanfaatkan 35 jenis (Tabel 2). Tumbuhan obat yang dimanfaatkan Suku Melayu lebih tinggi dibandingkan Suku Dayak, dan hal ini selaras dengan yang ditemukan pada Suku oleh Melayu dan Dayak Paus di Desa Pengadang Sanggau [2]. Rendahnya jenis-jenis tumbuhan yang dimanfaatkan suku Dayak dikarenakan tidak semua informasi dapat diberikan oleh Battra Suku Dayak karena adanya pantangan-pantangan tertentu yang tidak boleh dilanggar oleh mereka, dan secara umum pantangan tersebut oleh Suku Dayak disebut Pengkeras [2].

Diantara jenis-jenis tumbuhan obat yang digunakan oleh Battra Suku Melayu dan Suku Dayak Mahap, terdapat 15 jenis yang dimanfaatkan secara bersama seperti banglai, bungkang, dadup, cokur, cokur belangkin, jerangau, jungkal, keladi berlayar, keladi birah, kelor, kumis kucing, leyak merah, loban, mangkok, sorai, suruhan dan timau besi. Adanya kesamaan penggunaan tumbuhan oleh kedua suku tersebut mengindikasikan adanya distribusi pengetahuan yang sama antar suku dan hal tersebut diduga karena adanya interaksi antar masyarakat dalam desa tersebut [2].

\section{Famili tumbuhan obat yang dimanfaatkan oleh Battra}

Sebanyak 43 famili tumbuhan obat dimanfaatkan oleh Battra di Desa Tembesuk (Gambar 2). Battra Suku Melayu menggunakan 38 famili tumbuhan obat dan Suku Dayak Mahap 22 famili tumbuhan obat. Famili tumbuhan yang banyak digunakan oleh Battra di Desa Tembesuk adalah famili Zingiberaceae, dimana pada Suku Melayu terdapat 6 spesies tumbuhan obat dan pada Suku Dayak Mahap terdapat 5 spesies tumbuhan obat. Tingginya penggunaan famili Zingiberaceae juga ditemukan di wilayah lain di Kalimantan Barat seperti pada Battra Suku Melayu dan Dayak Ahe di Dusun Serambai Sanggau [16], dan Dayak Iban di Kapuas Hulu [7].

Tumbuhan yang dimanfaatkan Battra di Desa Tembesuk dan termasuk dalam famili Zingiberaceae adalah banglai/mangelai (Z. cassumunar), cokur (K. galanga), entomu (C. zanthorrhiza), kunyit (C. longa), kunyit putih (C. zedoaria), leyak (Z. officinale), dan leyak merah (Z. officinale Rosc. Var rubrum). Famili Zingiberaceae diketahui memiliki beberapa komponen kimia seperti minyak atsiri, pati dan tanin. Ref. [17] menyatakan bahwa kandungan minyak atsiri pada famili Zingiberaceae dapat digunakan sebagai antiseptik, pelancar darah, dan penenang. 


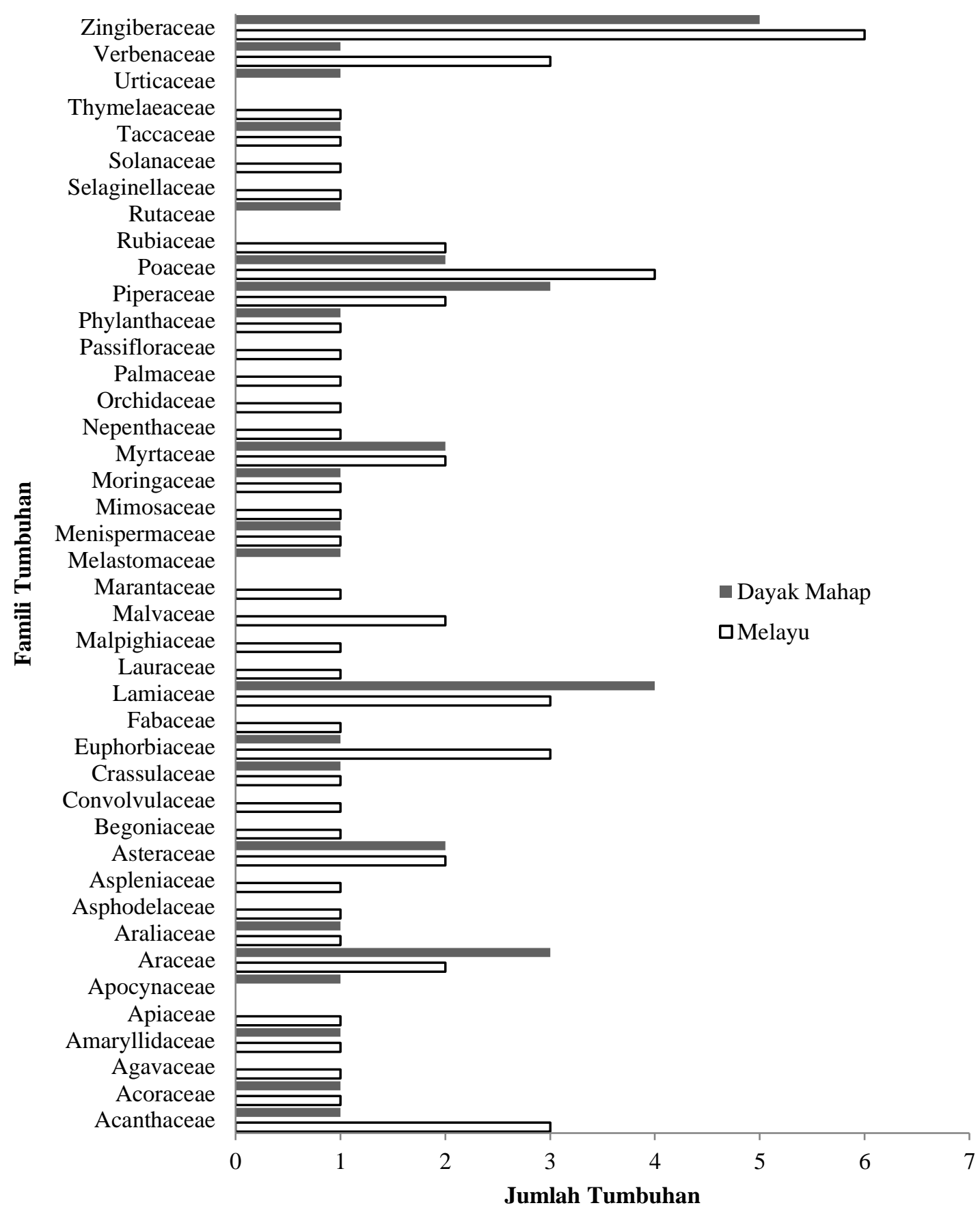

Gambar 2. Famili tumbuhan obat yang dimanfaatkan oleh Battra di Desa Tembesuk Sumber: Hasil analisis data, 2021

\section{Bagian tumbuhan yang dimanfaatkan oleh Battra}

Battra di Desa Tembesuk memanfaatkan beberapa bagian tumbuhan dalam proses pengobatan yang mereka lakukan antara lain kulit batang, umbi, bunga, akar, rimpang, batang, buah, daun, dan seluruh bagian. Bagian tumbuhan yang dominan dimanfaatkan oleh Battra di Desa Tembesuk adalah daun, dimana pada Suku Melayu sebesar 60\% dan Battra dari Suku Dayak Mahap sebesar 64,44\% (Gambar 3). Battra di Desa Tembesuk menyatakan bahwa bagian daun lebih mudah untuk ditemukan dan diambil serta tidak memberikan kerusakan yang berarti pada tumbuhan tersebut. Hal ini senada dengan yang ditemukan oleh ref. [18] pada Battra etnis Dayak di Desa Gerantung Bengkayang.

Daun merupakan salah satu bagian tumbuhan yang banyak mengandung senyawa bioaktif dan banyak digunakan dalam proses pengobatan tradisional. Salah satu contoh tumbuhan yang dimanfaatkan bagian daunnya oleh Battra Suku Melayu maupun Dayak Mahap di Desa Tembesuk adalah mangkok ( $N$. 
scutellarium). Daun mangkokan diketahui mengandung beberapa komponen senyawa bioaktif seperti alkaloid, fenol, flavonoid, kumarin, saponin, dan terpenoid [19].

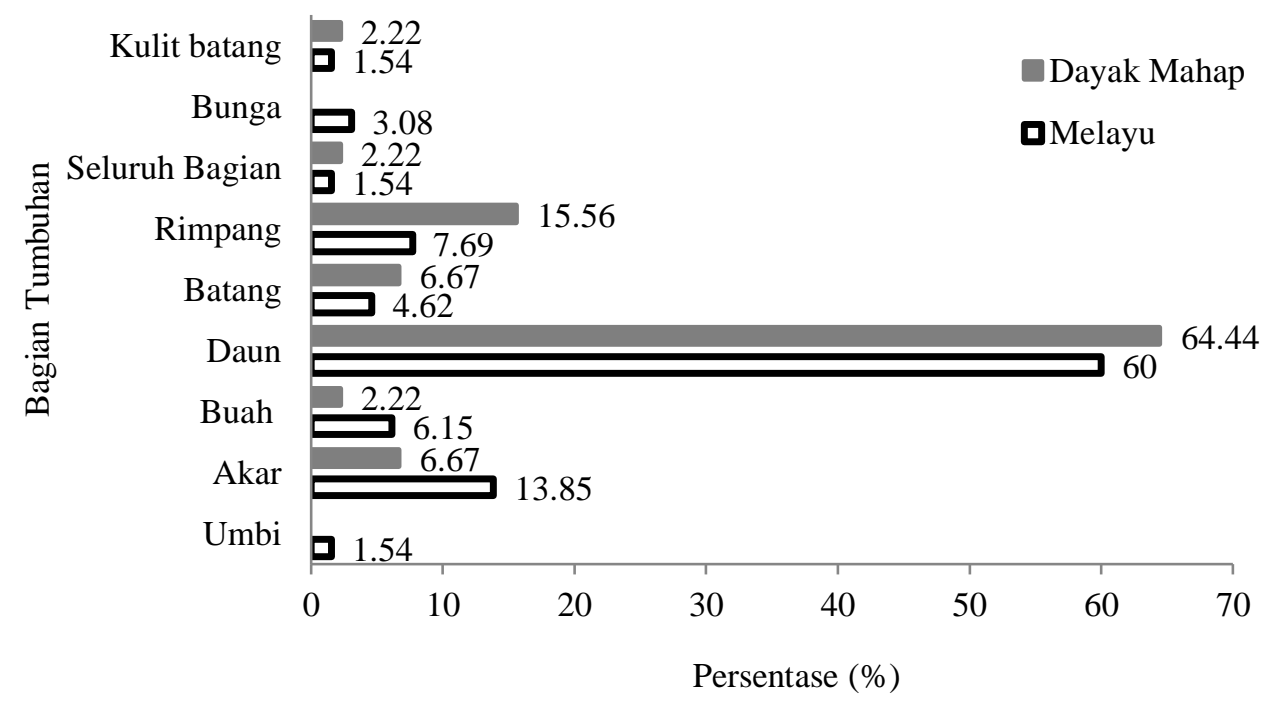

Gambar 3. Persentase pemanfaatan bagian tumbuhan obat oleh Battra di Desa Tembesuk Sumber: Hasil analisis data, 2021

\section{Cara pengolahan tumbuhan obat oleh Battra}

Battra di Desa Tembesuk mengolah tumbuhan obat dengan beragam cara seperti diseduh dengan air panas, dibakar, dilayur, diremas, diparut, direbus, ditumbuk dan tidak diolah (Gambar 4). Cara pengolahan tumbuhan obat yang paling tinggi dilakukan oleh Battra pada kedua suku adalah direbus yaitu Suku Melayu sebesar 41,54\% dan pada Suku Dayak Mahap sebesar 41,18\%. Hal ini senada dengan yang ditemukan ref. [8] pada Battra di Desa Masbangun Kayong Utara. Ref. [20] menjelaskan bahwa cara pengolahan direbus membuat zat yang terkandung pada tumbuhan lebih mudah larut sehingga akan bereaksi lebih cepat apabila diminum. Salah satu jenis tumbuhan yang dimanfaatkan oleh Battra di Desa Tembesuk dan cara pengolahannya dengan direbus adalah suruhan ( $P$. pellucida). Ref. [21] menyatakan bahwa ekstrak tumbuhan suruhan mengandung alkaloid, steroid, saponin, flavonoid, dan triterpenoid.

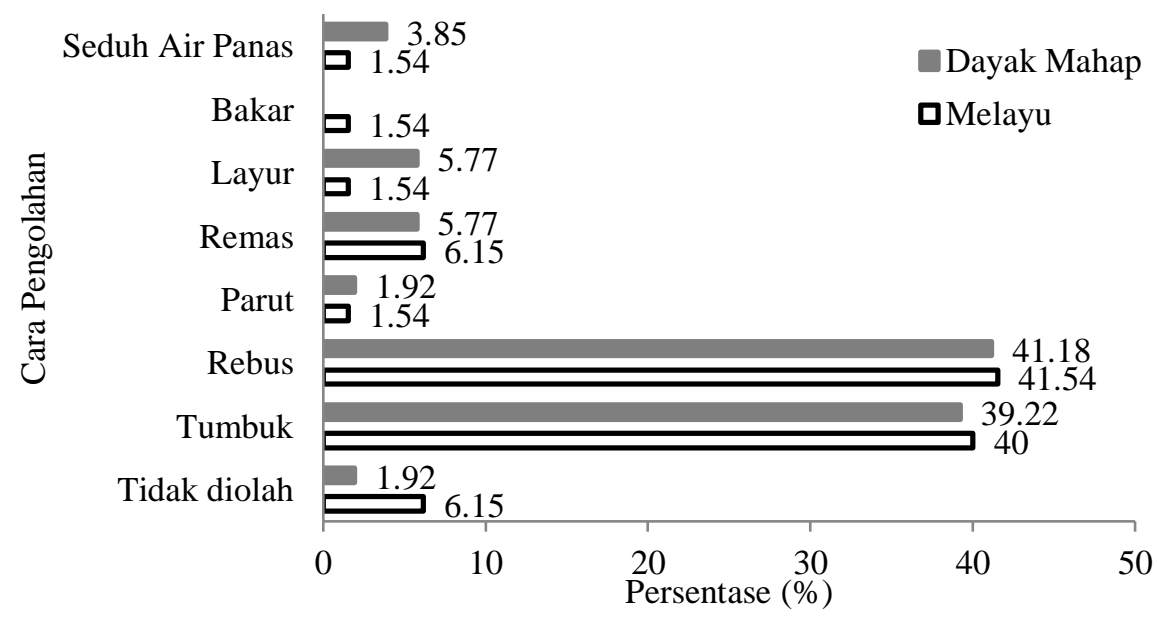

Gambar 4. Persentase cara pengolahan tumbuhan obat oleh Battra di Desa Tembesuk Sumber: Hasil analisis data, 2021

\section{Cara penggunaan tumbuhan obat oleh Battra}

Battra di Desa Tembesuk menggunakan tumbuhan obat dengan beragam cara seperti dimandikan, diikat, dikumur, dikompres, diminum, dimakan, dioles, digosok dan ditempel (Gambar 5). Cara penggunaan tumbuhan obat tertinggi oleh Battra di Desa Tembesuk adalah dengan diminum, dimana pada Suku Melayu sebesar 35,82\% dan Suku Dayak Mahap sebesar 41,18\%. Hal tesebut sesuai dengan yang diungkapkan oleh ref. [18] pada Battra etnis Dayak di Desa Gerantung Bengkayang. Battra di Desa Tembesuk menyatakan bahwa cara penggunaan dengan diminum diyakini sebagai cara penggunaan paling 
$\overline{\text { ampuh karena dengan meminum sama saja mengobati penyakit dari dalam tubuh. Salah satu tumbuhan obat }}$ yang cara penggunaannya diminum yaitu timau besi/nasik barek (C. longifolia). Penelitian yang dilakukan ref. [22] menyatakan bahwa $C$. longifolia memiliki kandungan alkaloid, flavonoid, dan steroid.

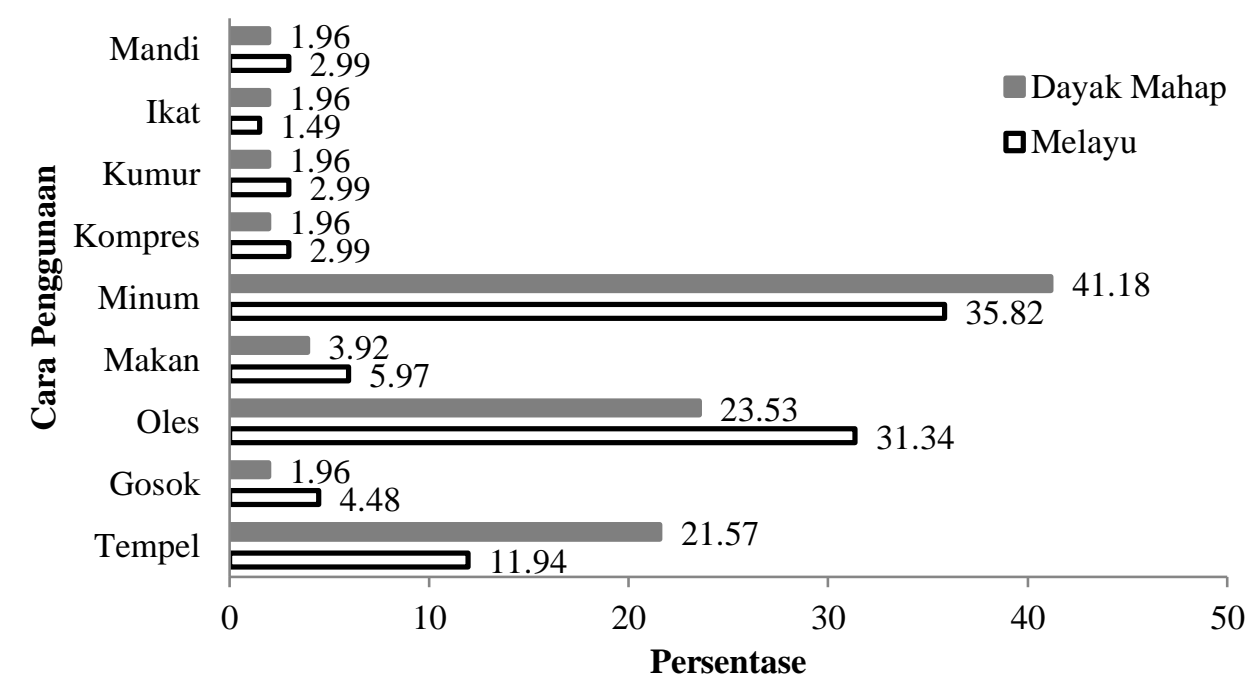

Gambar 5. Persentase cara penggunaan tumbuhan obat oleh Battra di Desa Tembesuk Sumber: Hasil analisis data, 2021

\section{Status tumbuhan obat yang dimanfaatkan oleh Battra}

Status tumbuhan obat yang dimaksud adalah apakah tumbuhan obat yang dimanfaatkan oleh Battra termasuk tumbuhan liar atau budidaya. Battra di Desa Tembesuk lebih dominan mengambil tumbuhan yang tumbuh secara liar, dimana pada Suku Melayu sebesar 66,67\% dan Suku Dayak Mahap sebesar 58,33\% (Gambar 6). Hal ini senada dengan yang ditemukan ref. [23] pada Battra dan masyarakat di Desa Sejahtera Kayong Utara. Tumbuhan obat yang dimanfaatkan oleh pengobat tradisional di Desa Tembesuk dan masuk kedalam status tumbuhan liar diantaranya jungkal (C. asiaticum), keladi berlayar/patah kemudi (E. scaber), keladi birah/keladi (C. esculenta), kelor (M. oleifera), sorai (C. citratus) loban (V. pubescens), suruhan ( $P$. pellucida) dan timau besi/nasi barek (C. longifolia).

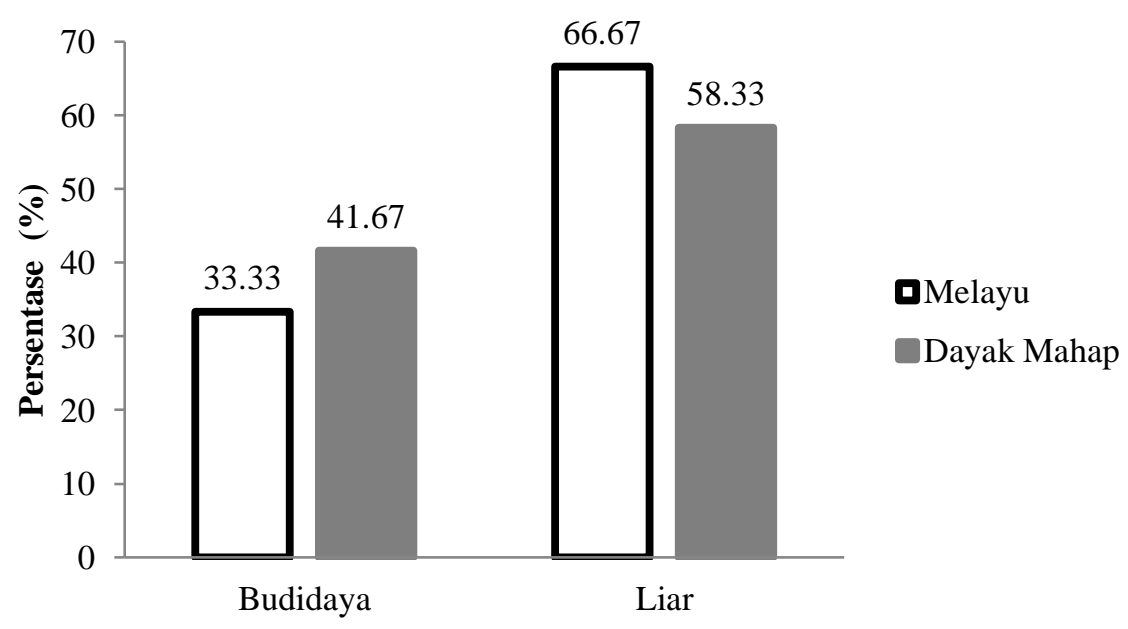

Gambar 6. Persentase status tumbuhan obat yang dimanfaatkan oleh Battra di Desa Tembesuk Sumber: Hasil analisis data, 2021

\section{Kesimpulan}

Tumbuhan obat bagi Battra di Desa Tembesuk Kabupaten Sekadau menjadi bagian yang tidak terpisahkan dalam proses pengobatan tradisional yang mereka lakukan. Sebanyak 80 jenis tumbuhan dimanfaatkan oleh Battra yang terdistribusi pada Suku Melayu sebanyak 60 jenis dan pada Suku Dayak Mahap sebanyak 35 jenis, dan 15 jenis diantaranya digunakan secara bersama oleh mereka. Famili 
tumbuhan yang dominan mereka gunakan adalah Zingiberaceae, dengan bagian tumbuhan tertinggi yang digunakan adalah daun, diolah dengan cara direbus dan digunakan dengan cara diminum. Tumbuhan obat digunakan oleh Battra dominannya adalah tumbuhan yang hidup secara liar. Adanya beragam jenis tumbuhan obat yang masih dimanfaatkan oleh Battra di Desa Tembesuk, maka perlu untuk dilakukan kajian lanjutan terkait apakah masyarakat umum masih menggunakan tumbuhan obat sebagaimana yang dimanfaatkan oleh Battra dan perlu pembuktian ilmiah terkait jenis-jenis tumbuhan yang dimanfaatkan oleh Battra Suku Melayu dan Suku Dayak Mahap di Desa Tembesuk.

\section{Ucapan Terima Kasih}

Penulis mengucapkan terima kasih kepada Battra di Desa Tembesuk, kepala desa dan perangkatnya serta pihak-pihak yang telah banyak membantu dalam penelitian ini.

\section{Referensi}

[1] S. Saudah, S. Rasnovi, dan Z. Zumaidar, "Tingkat pengenalan masyarakat terhadap jenis tumbuhan obat di Kecamatan Peusangan Selatan Kabupaten Bireun," J. Serambi Eng., vol. 4 (1), hal. 392, 2019, doi: 10.32672/jse.v4i1.849.

[2] S. Pradita, Y. Mariani, E. Wardenaar, dan F. Yusro., "Pemanfaatan tumbuhan obat oleh Suku Dayak Paus dan Melayu untuk perawatan ibu dan anak pasca persalinan di Desa Pengadang Kabupaten Sanggau Kalimantan Barat," Biodidaktika J. Biol. dan Pembelajarannya, vol. 16 (1), hal. 93-110, 2021, [Online]. Available: http://dx.doi.org/10.30870/biodidaktika.v16i1.10805.

[3] F. Yusro, R. N. Pranaka, I. Budiastutik, dan Y. Mariani, "Pemanfaatan tumbuhan obat oleh masyarakat sekitar taman wisata alam (TWA) Bukit Kelam, Kabupaten Sintang, Kalimantan Barat," J. Sylva Lestari, vol. 8 (2), hal. 255-272, 2020, doi: http://dx.doi.org/10.23960/jsl28255-272.

[4] F. Yusro, R. N. Pranaka, I. Budiastutik, and Y. Mariani, "Diversity of medicinal plants used by traditional healers of Dayak Desa Tribe in the Villages of Kebong and Merpak, Sintang Regency," J. Biol. Trop., vol. 20 (3), hal. 329 - 339, 2020, doi: 10.29303/jbt.v20i3.2010.

[5] R. N. Pranaka, F. Yusro, dan I. Budiastutik, "Pemanfaatan tanaman obat oleh masyarakat Suku Melayu di Kabupaten Sambas," J. Tumbuh. Obat Indones., vol. 13 (1), hal. 1-24, 2020, doi: 10.22435/jtoi.v13i1.1887.

[6] R. P. Sari, F. Yusro, and Y. Mariani, "Medicinal plants used by Dayak Kanayatan traditional healers in Tonang Village Sengah Temila District Landak Regency," J. Biol. Trop., vol. 21 (2), p. 324, 2021, doi: 10.29303/jbt.v21i2.2557.

[7] F. Yusro, Y. Mariani, dan E. Wardenaar, "Pemanfaatan tumbuhan obat untuk mengatasi gangguan sistem pencernaan oleh Suku Dayak Iban: studi kasus di Kabupaten Kapuas Hulu Kalimantan Barat," J. Borneo Akcaya, vol. 5 (1), hal. 58-72, 2019.

[8] Rania, F. Yusro, E. Wardenaar, dan Y. Mariani, "Studi pemanfaatan tumbuhan obat oleh pengobat tradisional untuk mengatasi masalah kewanitaan di Desa Masbangun Kecamatan Teluk Batang Kabupaten Kayong Utara," J. Borneo Akcaya, vol. 5 (2), hal. 84-94, 2019.

[9] D. Sulatri, E. Roslinda, dan Y. Mariani, "Pemanfaatan tumbuhan obat oleh masyarakat di sekitar Hutan Adat Tawang Panyai di Desa Tapang Semadak Kecamatan Sekadau Hilir Kabupaten Sekadau," J. Hutan Lestari, vol. 7 (1), hal. 597-616, 2019, doi: 10.26418/jhl.v7i1.32739.

[10] F. Yusro, Y. Mariani, F. Diba, and K. Ohtani, "Inventory of medicinal plants for fever used by four Dayak Sub Ethnic in West Kalimantan, Indonesia,” Kuroshio Sci., vol. 8, no. 1, pp. 33-38, 2014, [Online].

Available: https://pdfs.semanticscholar.org/85de/a1079c6fb510e349c126eed288aeb485162b.pdf?_ga=2.2379 37280.1828213471.1561974200-652424871.1561974200.

[11] F. Yusro, Y. Mariani, and E. Wardenaar, "The utilization of medicinal plants to overcome gastric disorders by The Dayak Muara Tribe in Kuala Dua Village, Sanggau Regency," J. Biol. Trop., vol. 21 (2), pp. 416-426, 2021, doi: 10.29303/jbt.v21i2.2638.

[12] F. Yusro, Y. Mariani, E. Wardenaar, dan Yanieta Arbiastutie, Database Tumbuhan Obat Tradisional Kalimantan Barat, CV Mitra Natawana, Yogyakarta, 2020.

[13] J. M. Andrade, H. L. Mosquera, and C. Armijos, "Ethnobotany of indigenous saraguros: medicinal plants used by community healers "Hampiyachakkuna" in the San Lucas Parish, Southern Ecuador," Biomed Res. Int., vol. 2017, pp. 1-20, 2017, doi: 10.1155/2017/9343724.

[14] R. Due, Symaswisna, dan R. Marlina, "Etnobotani tumbuhan obat Suku Dayak Pesaguan dan implementasinya dalam pembuatan flash card biodiversitas," J. Pendidik. dan Pembelajaran Katulistiwa, vol. 3 (2), hal. 1-15, 2014, [Online]. Available: 
https://jurnal.untan.ac.id/index.php/jpdpb/article/view/4616/4697.

[15] R. Riconadi, Y. Arbiastutie, Y. Mariani, L. Sisillia, dan F. Yusro, "Studi pemanfaatan tumbuhan obat sebagai tonik oleh pengobat tradisional di Desa Karya Bakti Kecamatan Sungai Betung Kabupaten Bengkayang," J. Hutan Lestari, vol. 8 (3), hal. 640-652, 2020, doi: 10.26418/jhl.v8i3.42734.

[16] R. Y. Sari, E. Wardenaar, dan Muflihati, "Etnobotani tumbuhan obat di Dusun Serambai Kecamatan Kembayan Kabupaten Sanggau Kalimantan Barat," J. Hutan Lestari, vol. 2 (3), hal. 379-387, 2014.

[17] S. Hartanto, Fitmawati, dan N. Sofiyanti, "Studi etnobotani famili Zingiberaceae dalam kehidupan masyarakat lokal di Kecamatan Pangean Kabupaten Kuantan Singingi, Riau," Biosaintifika J. Biol. Biol. Educ., vol. 6 (2), hal. 98-108, 2014, doi: 10.15294/biosaintifika.v6i2.3105.

[18] D. Gunadi, H. A. Oramahi, dan G. E. Tavita, "Studi tumbuhan obat pada etnis dayak di Desa Gerantung Kecamatan Monterado Kabupaten Bengkayang," J. Hutan Lestari, vol. 5 (2), hal. 425 436, 2017.

[19] I. Ahdiyah dan K. I. Purwani, "Pengaruh ekstrak daun Mangkokan (Nothopanax scutellarium) sebagai larvasida nyamuk Culex sp.," J. Sains dan Seni ITS, vol. 4 (2), hal. 2337-3520, 2015.

[20] J. Syah, F. H. Usman, dan F. Yusro, "Studi etnobotani tumbuhan obat yang di manfaatkan masyarakat Dusun Nekbare Desa Babane Kecamatan Samalantan Kabupaten Bengkayang," J. Hutan Lestari, vol. 3 (2), hal. 419-426, 2014, doi: 10.26418/jhl.v2i3.7495.

[21] N. Bialangi, M. A. Mustapa, Y. K. Salimi, A. Widiantoro, and B. Situmeang, "Antimalarial activity and phitochemical analysis from Suruhan (Peperomia pellucida) extract," J. Pendidik. Kim., vol. 8 (3), hal. 183-187, 2016.

[22] N. Qamariah, R. Handayani, dan A. Khadafi, "Pemanfaatan tumbuhan Sangkareho (Callicarpa longifolia Lam) asal Kalimantan Tengah sebagai obat tradisional," J. Surya Med., vol. 2 (1), hal. 14-22, 2016.

[23] S. Aminah, E. Wardenaar, dan Muflihati, "Tumbuhan obat yang dimanfaatkan oleh Battra di Desa Sejahtera Kecamatan Sukadana Kabupaten Kayong Utara," J. Hutan Lestari, vol. 4 (3), hal. 299 305, 2016, doi: 10.26418/jhl.v4i3.16144. 